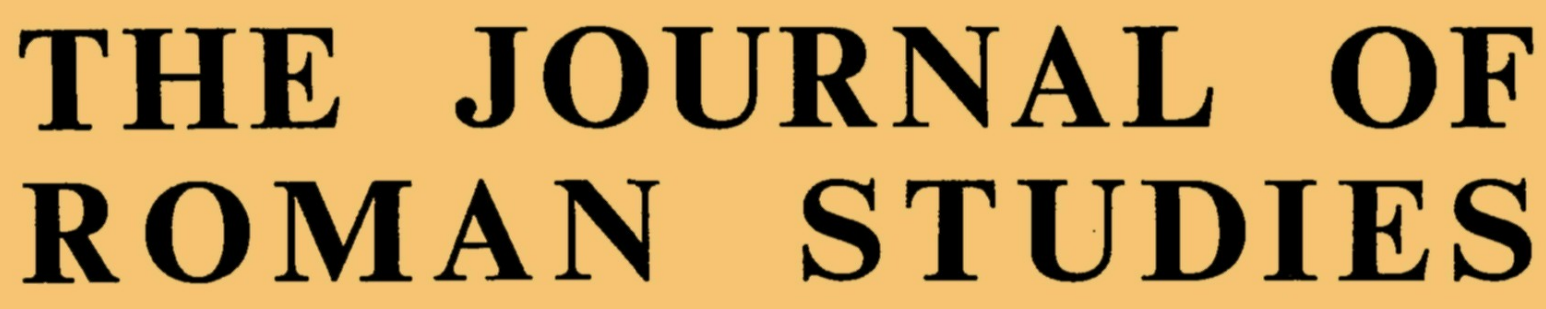

VOLUME LIV

\title{
CONTENTS
}

Margerie Venables Taylor

A Bibliography of the Published Writings of Margerie Venables Taylor

J. M. C. Toynbee, A New Roman Mosaic Pavement found in Dorset

Alan Cameron, The Roman Friends of Ammianus

M. H. Crawford, War and Finance

Fergus Millar, The Aerarium and its Officials under the Empire

G. V. Sumner, Manius or Mamercus ?

Ramsay MacMullen, Social Mobility and the Theodosian Code

W. H. Manning, The Plough in Roman Britain

John Briscoe, Q. Marcius Philippus and Nova Sapientia

A. H. M. Jones, Collegiate Prefectures

Michael Winterbottom, Quintilian and the Vir Bonus

Barbara Levick and Shelagh Jameson, C. Crepereius Gallus and his Gens

P. R. L. Brown, St. Augustine's Attitude to Religious Coercion

P. R. C. Weaver, Vicarius and Vicarianus in the Familia Caesaris

M. W. Frederiksen, The Lex Rubria : reconsiderations

Frank D. Gilliard, Notes on the Coinage of Julian the Apostate

Ronald Syme, Hadrian and Italica

R. P. Wright, Two New Items in the Army List of Roman Britain

Roman Britain in 1963. I. Sites Explored (by D. R. Wilson). II. Inscriptions (by R. P. Wright)

REVIEW AND DISCUSSION

C. O. Brink, Horace on Poetry (by Gordon Williams)

\section{REVIEWS AND NOTICES OF PUBLICATIONS}

(See List of Contents)

List of Works received

Proceedings of the Society, 1963-1964

Report of the Council for 1963

Balance Sheet as at 31st December, 1963

Income and Expenditure Account for the year ended 31st December, 1963

Joint Library Account for the year ended 31st December, 1963
Indexes :-

(i) Names and Subjects

(ii) Literary Authorities

(iii) Inscriptions

(iv) Papyri

(v) Coins 


\section{THE JOURNAL OF \\ ROMAN STUDIES}


WITH ACKNOWLEDGMENT TO

THE BRITISH ACADEMY ALL SOULS FUND

AND THE JOWETT COPYRIGHT TRUSTEES

All rights reserved 


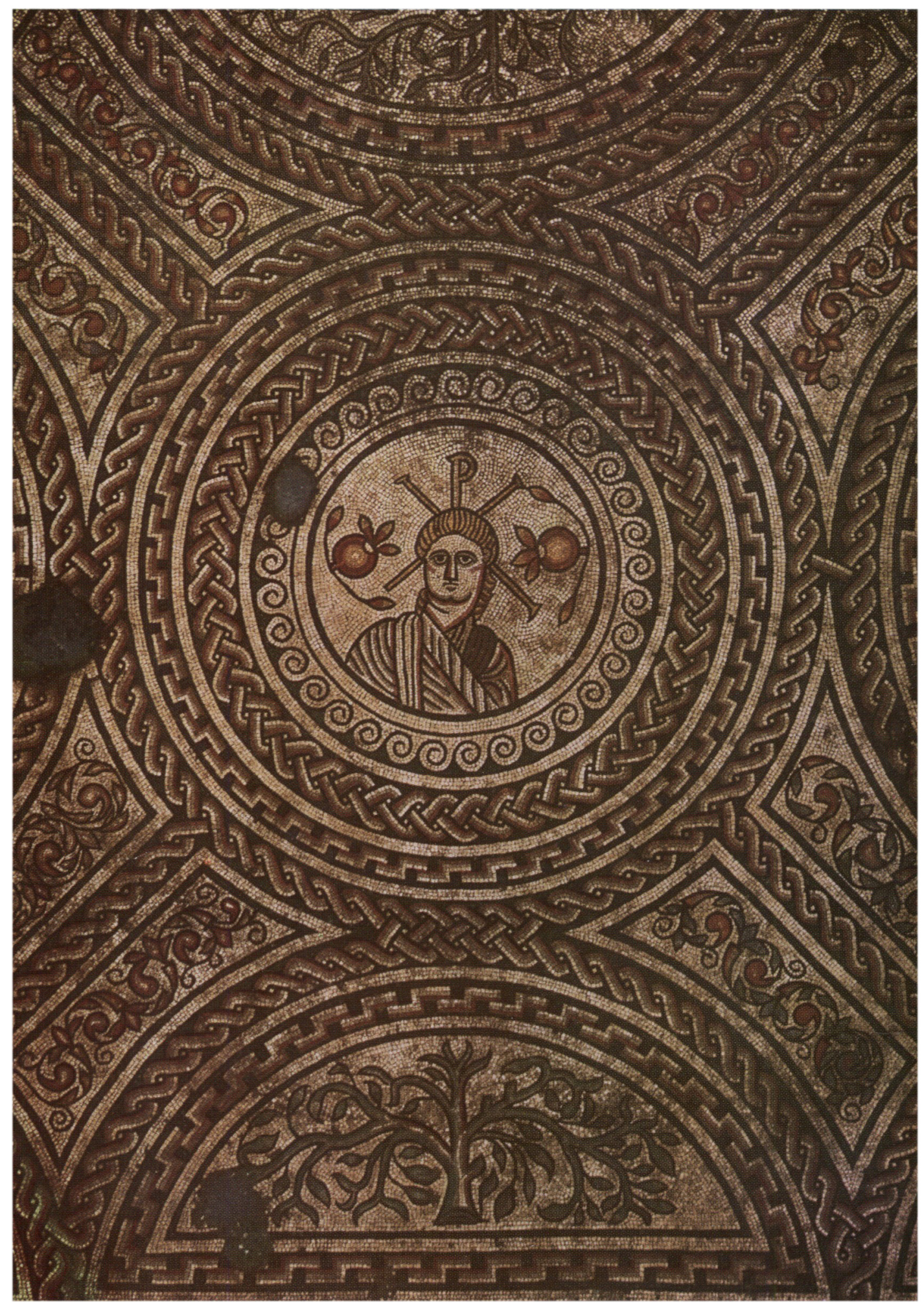

IINTON ST. MARY, DORSET: PANEL OF FOURTH-CENTLRY MOSAIC PAVEMENT FEATLRING MALE BUST With CHI-RHO AND POMEGRANATES (see p. 8)

Photograph by Royal Commission on Historical Monuments, England. Copyright W. $\mathcal{F}$. White 


\section{THE JOURNAL OF ROMAN STUDIES}

\section{VOLUME LIV}

PUBLISHED BY THE SOCIETY FOR THE PROMOTION OF ROMAN STUDIES AT THE OFFICE OF THE SOCIETY, 31-34 GORDON SQUARE, LONDON, W.C.1 1964 


\section{CONTENTS}

Margerie Venables Taylor

A Bibliography of the Published Writings of Margerie Venables Taylor

J. M. C. ToynbeE, A New Roman Mosaic Pavement found in Dorset $\quad$. $\quad$. $\quad$. $\quad$. 7

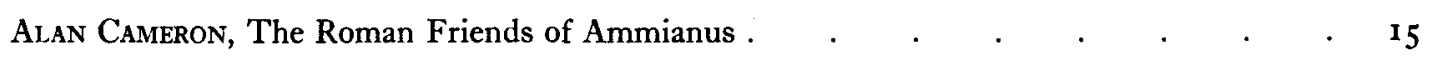

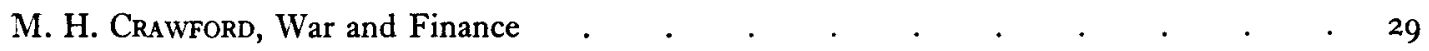

Fergus Millar, The Aerarium and its Officials under the Empire . . . . . $\quad 33$

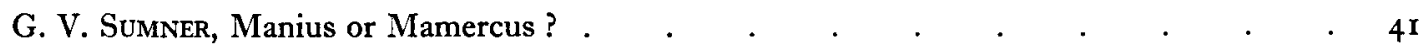

Ramsay MacMullen, Social Mobility and the Theodosian Code . . . . . . . $\quad$. 49

W. H. Manning, The Plough in Roman Britain $\quad . \quad$. $\quad . \quad$. $\quad . \quad$. $\quad . \quad 54$

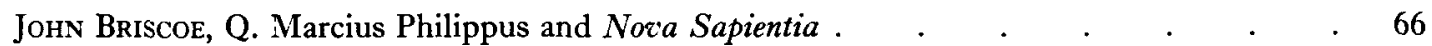

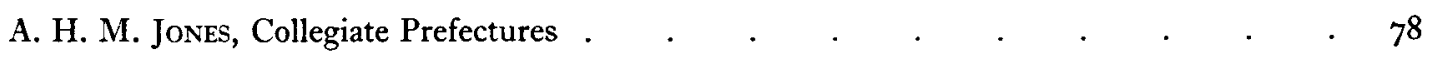

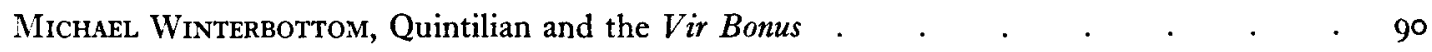

Barbara Levick and Shelagh Jameson, C. Crepereius Gallus and his Gens . . $\quad 98$

P. R. L. Brown, St. Augustine's Attitude to Religious Coercion . . . . . . . . 107

P. R. C. Weaver, Vicarius and Vicarianus in the Familia Caesaris . . . . . . . . . II7

M. W. Frederiksen, The Lex Rubria : reconsiderations . . . . . . . . . . . I 29

Frank D. Gilliard, Notes on the Coinage of Julian the Apostate . . . . . . . $\quad$ I35

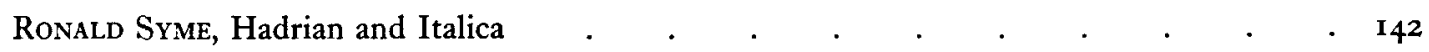

R. P. Wright, Two New Items in the Army List of Roman Britain . . . . . ${ }_{150}$

Roman Britain in I963. I. Sites Explored (by D. R. Wilson) . . . . . . . . $\mathbf{I}_{52}$

II. Inscriptions (by R. P. Wright) . . . . . $\quad$. $\quad$ 177

\section{REVIEW AND DISCUSSION}

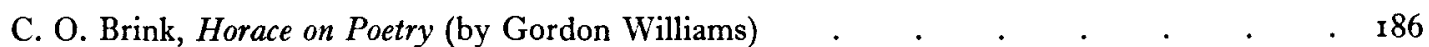

\section{REVIEWS AND NOTICES OF PUBLICATIONS REVIEWS}

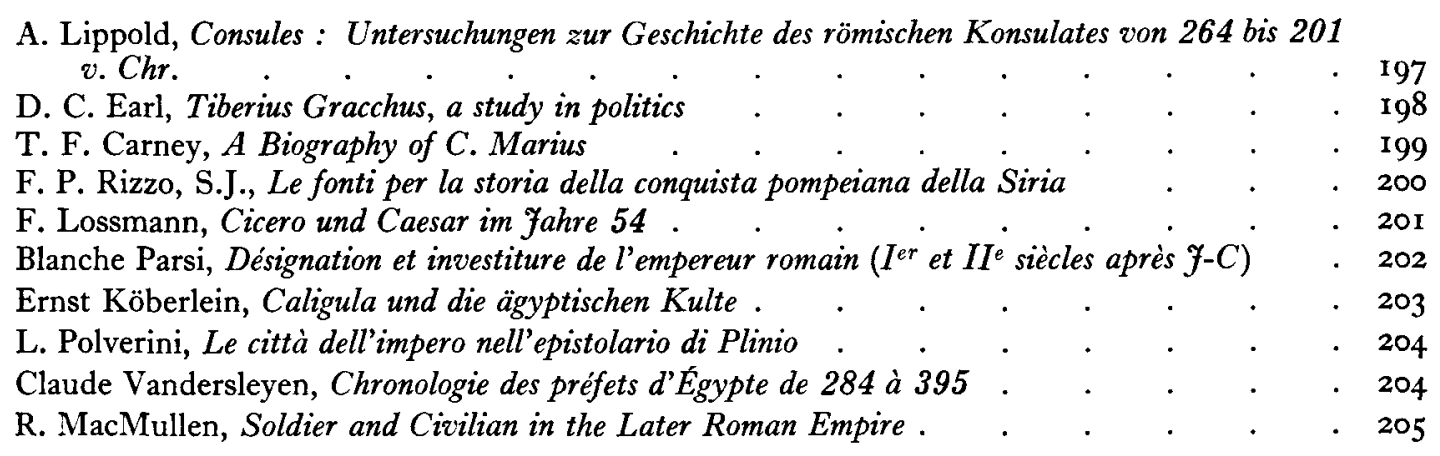


A. Momigliano (ed.), The Conflict between Paganism and Christianity in the Fourth Century .

Herbert Hunger, Prooimion. Elemente der byzantinischen Kaiseridee in den Arengen der Urkunden

W. Kunkel, Untersuchungen zur Entwicklung des roemischen Kriminalverfahrens in vorsullanischer Zeit

A. M. Honoré, Gaius, a biography .

D. Medicus, Id quod interest .

Jacques Michel, Gratuité en droit romain

F. de Visscher, Le Droit des tombeaux romains .

M. Bretone, La nozione romana di usufrutto, I .

L. Labruna, Rescriptum divi Pii : gli atti del pupillo sine tutoris auctoritat

Reinhold Merkelbach, Isisfeste in griechisch-römischer Zeit .

C. Herrmann, Le rôle judiciaire et politique des femmes sous la république romaine . . . . 2 6

J. Lindsay, Daily Life in Roman Egypt . . . . . . . . . . . . . . . . 2I7

M. Grant, Myths of the Greeks and Romans . . . . . . . . . . . . . . $\quad .218$

Raymond Bloch, Les prodiges dans l'antiquité classique . . . . . . . . . . . . . 218

Hugo Rahner, Greek Myths and Christian Mystery . . . . . . . . . . . 2 I9

Pierre Wuilleumier, Inscriptions latines des Trois Gaules . . . . . . . . . . $\quad 220$

Iiro Kajanto, Onomastic Studies in the Early Christian Inscriptions of Rome and Carthage $\quad$. $22 \mathrm{I}$

Iiro Kajanto, A Study of the Greek Epitaphs of Rome _ . . . . . . . . . . . . 221

W. H. Gross, Iulia Augusta : Untersuchungen zur Grundlegung einer Livia-Ikonographie $\quad .222$

Richard Brilliant, Gesture and Rank in Roman Art . . . . . . . . . . . $\quad . \quad 223$

E. von Mercklin, Antike Figuralkapitelle . . . . . . . . . . . . . . . $\quad . \quad 224$

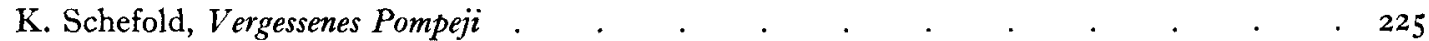

Iosephus Lugli, Fontes ad topographiam veteris urbis Romae pertinentes, viII . . . . $\quad$ - 226

Luigi Beschi, I bronzetti romani di Montorio Veronese _ . . . . . . . . . . . $\quad 227$

R. F. Tylecote, Metallurgy in Archaeology . . . . . . . . . . . . . . . . . . . . $\quad .228$

Leo Biek, Archaeology and the Microscope . . . . . . . . . . . . . . . . $\quad .229$

Paul MacKendrick, The Mute Stones Speak : the story of Archaeology in Italy . . . 230

P.-M. Duval, Paris antique, des origines au troisième siècle . . . . . . . . . 230

R. Noll, Das römerzeitliche Gräberfeld von Salurn . . . . . . . . . . . . $\quad$. $23 \mathrm{I}$

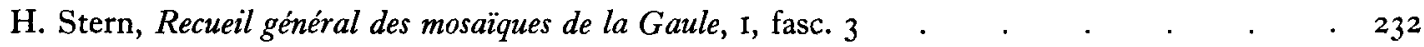

A. Garcia Bellido and J. Menendez Pidal, El distylo sepulcral romano de Iulipa (Zalamea) $\quad 233$

Gustav Müller, Untersuchungen am Kastell Butzbach . . . . . . . . . . $\quad 234$

Hans Schönberger, Neuere Grabungen an obergermanischen und rätischen Limes . . $\quad . \quad 234$

Peter Hunter Blair, Roman Britain and Early England 55 B.C.-A.D. 871 . . . . $\quad .235$

Victoria County History of Essex III, Roman Essex . . . . . . . . . . . . . $\quad$. 235

J. M. C. ToynbeE, A Silver Casket and Strainer from the Walbrook Mithraeum in the City of London

M. R. Hull, The Roman Potters' Kilns of Colchester .

Frank Olivier, Essais dans le domaine du monde gréco-romain antique et dans celui du Nouveau Testament

L. P. Wilkinson, Golden Latin Artistry . . . . . . . . . . . . . . . 23

Giusto Monaco, Teatro di Plauto, 1 : Il curculio . . . . . . . . . . . $\quad 240$

Plautus, Miles Gloriosus (ed. M. Hammond, A. M. Mack and W. Moskalew) . . . 240

P. McGlynn, Lexicon Terentianum I, A-O . . . . . . . . . . . . . . . . 24I

K. Barwick, Das rednerische Bildungsideal Ciceros . . . . . . . . . . . . $\quad .242$

Virgil, Georgics I and IV (ed. H. H. Huxley) . $\quad$. . . . . . . . . . . $\quad . \quad 243$

R. G. Austin, Virgil Aeneid II with a commentary . . . . . . . . . . . . . $\quad .244$

Brooks Otis, Virgil, a study in civilized poetry . . . . . . . . . . . 246

Bruno Nardi, Mantuanitas Vergiliana . . . . . . . . . . . . $\quad .250$

P. J. Enk, Sex. Propertii Elegiarum liber secundus . . . . . . . . . $\quad$. $25^{\circ}$

Giuseppe G. Bianca, La pedagogia di Quintiliano . . . . . . . . . . . . . $\quad$. $25 \mathbf{I}$ 
R. A. B. Mynors, C. Plini Secundi Epistularum libri decem . . . . . . . . . . . $\quad 252$

P. Cornelius Tacitus, Die Historien, I ; erstes Buch (Kommentar von Heinz Heubner) . $\quad 254$

Cornelius Tacitus, Annalen I, Buch 1-3 (erläutert von Erich Koestermann) . . . 255

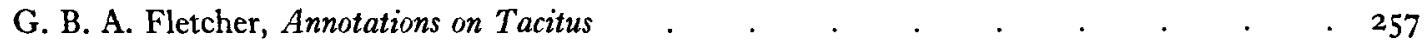

\section{NOTICES}

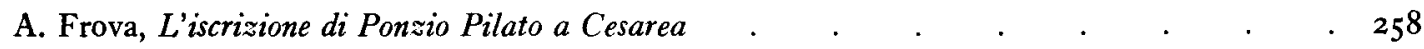

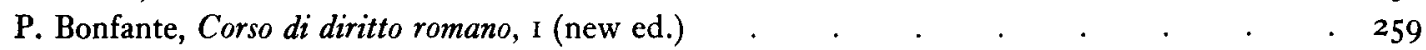

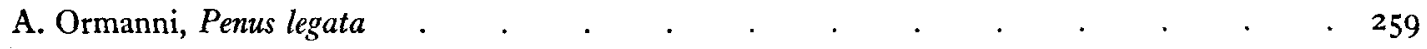

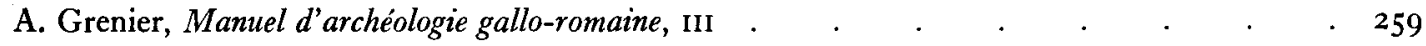

Atti del settimo Congresso internazionale di Archeologia classica . . . . . . . . . . . . $\quad$. 260

Kenneth Quinn, Latin Explorations : critical studies in Roman Literature . . . $\quad 260$

Lesley Lewis, Connoisseurs and Secret Agents in eighteenth-century Rome . . . . . . 26I

John Fleming, Robert Adam and his Circle in Edinburgh and Rome . . . . . . . . . $26 \mathrm{I}$

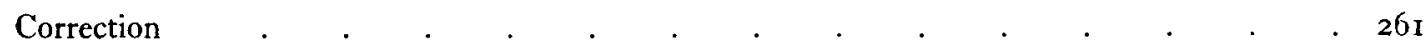

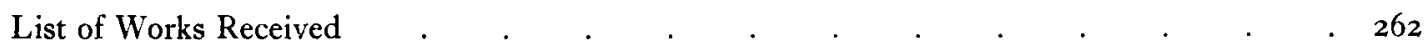

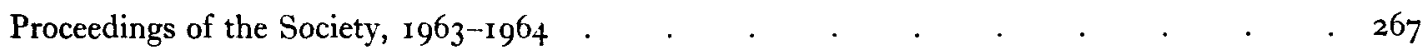

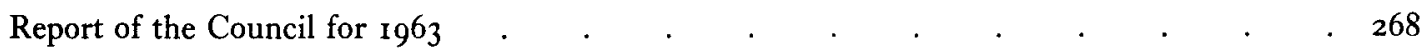

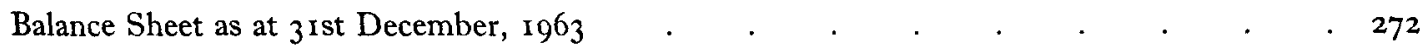

Income and Expenditure Account for the year ended 3 ist December, 1963 . . . . . 273

Joint Library Account for the year ended 3ist December, 1963 . . . . . . . . . 274

Indexes :-

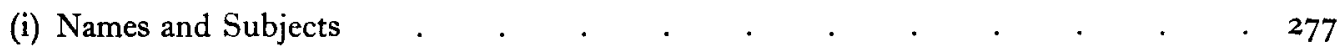

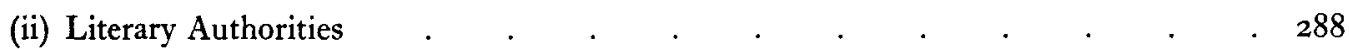

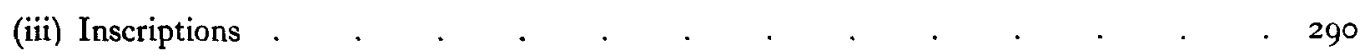

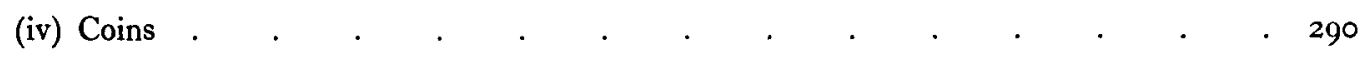

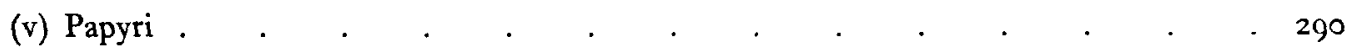




\section{LIST OF PLATES}

J. M. C. Toynbee, A New Roman Pavement Found in Dorset.

Frontispiece. Detail in colour of male bust with chi-rho and pomegranates.

Plate I. Detail in colour of Bellerophon slaying the Chimaera.

II. E. portion of pavement.

III. W. portion of pavement.

Iv. Details of half-circles :

I. Hound pursuing stag.

2. Hound pursuing hind.

3. Tree.

v. I. Corner-bust with pomegranates.

2. Corner-bust with rosettes.

3. Panel of hound pursuing stag and hind.

vi. Silver plate in Geneva, showing emperor with nimbus bearing chi-rho.

viI. I. Metropolitan Museum, New York : bust of St. Laurence on gold-glass medallion.

2. British Museum, London : bust of Christ on gold-glass medallion.

3. S. Sabina, Rome: wooden door-panel, showing Christ with chi-rho.

4. S. Lorenzo, Milan: figure of Christ on vault-mosaic in Cappella di S. Aquilino.

W. H. Manning, The Plough in Roman Britain.

Plate vili. I. Bronze model plough from Cologne.

2. Tip of bar-share from Silchester.

3. Long flanged-share from Walthamstow, Essex.

4. Coulter-blade from Twyford Down, Hants.

5. Alleged Belgic coulter from Bigbury, Kent.

6, 7. Tanged share from Box villa, Wilts.

Barbara Levick and Shelagh Jameson, C. Crepereius Gallus and his Gens.

Plate Ix. Honorific inscription from Antioch-towards-Pisidia.

Frank D. Gilliard, Notes on the Coinage of Julian the Apostate.

Plate $\quad x$. Coins of the American Numismatic Society illustrating some types of Julian.

Roman Britain in 1963 .

Plate XI. I. Caerleon, Mon.: third-century quay on R. Usk.

2. Birrens, Dumfriess. : late-Antonine oven in E. rampart of fort.

xII. I. Lincoln : masonry of N. tower of E. gate and colonia wall-foundations.

2. Swanpool, Lincs : two fourth-century kilns.

3. Wroxeter, Salop: stone base for post of timber bridge.

xIII. I. Thorpe, Notts : aerial view of first-century fort and later walled settlement, from WSW.

2. Eccles, Aylesford, Kent : laconicum of first-century baths of villa.

xIv. New Fishbourne, Sussex : mosaic pavements in the palace :

I. In Room I I (late-first-century).

2. In Room 3 (late-second-century).

xv. I. Whitcombe, Dorset : limestone relief of bearded horseman.

2. Blackfriars, London : piece of leather decorated with dolphin, from wreck of sailing barge.

3, 4. Welwyn, Herts : haematite amulet.

xvi. I. Westerwood, Cumbernauld, Dunbartons. : sandstone altar to Silvanae and Quadruae Caelestes.

2. Caves Inn, Shawell, Leics : milestone of Constantine I. 


\section{LIST OF ILLUSTRATIONS IN THE TEXT}

J. M. C. Toynbee, A New Roman Pavement Found in Dorset.

Fig. I. Simplified diagram of decorative scheme of pavement .

W. H. Manning, The Plough in Roman Britain.

Fig. 2. Diagram of bow-ard

Fig. 3. a. The Donnerupland ard and its parts.

$b$. The Trollerup ard

Fig. 4. A. Bronze model plough, from Sussex.

B. Bronze model of a ploughman and his team, from Piercebridge, Co. Durham $5^{6}$

Fig. 5. A. Bar-share from Silchester.

B. Coulter from Silchester.

c. Asymmetrical share from Dinorben.

D. Short flanged-share from Silchester.

E. Short flanged-share from Wallingford.

F. Flanged-share from Bucklesbury House.

G. Short, pointed, flanged-share from Hunsbury.

H. Tanged share with spatulate blade from Hunsbury .

Fig. 6. A. Socketed bar-share from Woodcuts.

B, C. Iron tips of wooden bar-shares from Woodcuts.

D. Iron tips of wooden bar-shares from Brading.

E. Spear-share from Saalburg .

Fig. 7. Diagram of plough with coulter, winged share and mould-board . . . $\quad 63$

Roman Britain in 1963 .

Fig. 8. Inchtuthill, Perthshire : plan of temporary stores-compound _ . . . $\quad$ I54

Fig. 9. Rudston, E. Yorks : plan of house containing fourth-century mosaics . $\quad{ }_{156}$

Fig. 10. Winterton, Lincs : plan of buildings subsidiary to large house . . . $\quad$. 157

Fig. II. Ancaster, Lincs : section of E. defences of town . . . . . . . . $15^{8}$

Fig. 12. Thorpe, Notts : plan of posting-station on site of early fort . . . . . 160

Fig. 13. Leicester : plan of presumed forum . . . . . . . . . $16 \mathrm{I}$

Fig. 14. Wroxeter, Salop: plan of timber buildings of $c$. A.D. $60-78$, beneath second-

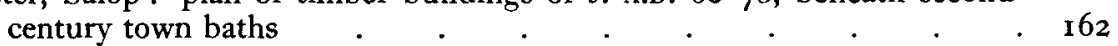

Fig. 15. Wroxeter, Salop : town plan . . . . . . . . . . . 163

Fig. 16. Lydham, Salop : plan of fort, later reduced to fortlet . . . . . . $\quad$ 164

Fig. 17. Shakenoak Farm, Wilcote, Oxon: plan of final phase of late-fourth-century house . . . . . . . . . . . 165

Fig. 18. Dorchester on Thames, Oxon: section of S town defences . . . . . 166

Fig. 19. Dorchester on Thames, Oxon : town-plan . . . . . . . . $\quad{ }_{167}$

Fig. 20. Blackfriars, London : plan and section of Roman sailing barge . . . . $\quad$ r68

Fig. 21. Cheapside, London : plan of site . . . . . . . . . . . 169

Fig. 22. Cirencester, Glos : plan of forum . . . . . . . . . . 170

Fig. 23. Winchester, Hants : town-plan. . . . . . . . . . . . . $\quad{ }_{172}$

Fig. 24. Portchester Castle, Hants : plan of E. gate . _ . . . . . . . . . $\quad$. 173

Fig. 25. New Fishbourne, Sussex : plan of late-first-century palace . . . . . 174

Fig. 26. New Fishbourne, Sussex : plan of NW. corner of palace . . . . $\quad$. 175

Fig. 27. Eccles, Aylesford, Kent : plans of the bath wing of large house in succeeding periods 


\section{SOCIETY FOR THE PROMOTION \\ OF ROMAN STUDIES}

\section{OFFICERS AND COUNCIL, I964-65}

\section{President}

PROFESSOR F. W. WALBANK, F.B.A.

\section{Vice-Presidents}

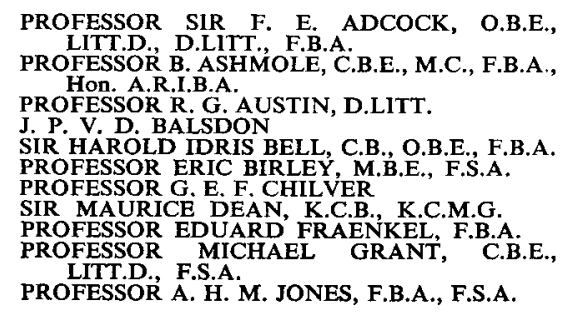

I. D. MARGARY, F.S.A.

PROFESSOR A. D. MOMIGLIANO, D.LITT., J. N. L. M.ARES, LL.D. F.S.A.

PROFESSOR SIR IAN RICHMOND, C.B.E., LITT.D., D.LIT., LL.D., F.B.A., P.S.A.
PROFESSOR H. H. SCULLARD, F.B.A., F.S.A. PROFESSOR H. H. SCULLARD, F.B.A., F.S.A. A. N. SHERWIN-WHITE, F.B.A.
PROFESSOR SIR RONALD SYME, D.LITT, F.B.A.
PROFESSOR J. M. C. TOYNBEE, D.PHIL. PROFESSOR J. M. C. TOYNBEE, D.PH J. B. WARD PERKINS, C.B.E., F.B.A., F.S.A. PROFESSOR A. H. M. JONES, F.B.A., F.S.A. D.LIT., D.LITT,, F.B.A., F.S.A.

\section{Ordinary Members of the Council}

PROFESSOR M. L. CLARKE

Elected June 1962

DR. D. C. EARL

R. M. OGILVIE

MISS A.S. ROBERTSON, F.S.A.

G. S. WACHER, F.S.A.

J. ANDERSON

Elected June 1963

F. A. LEPPER

DR. J. K. ST. JOSEPH, O.B.E., F.S.A.
DR. A. H. MCDONALD

Hon. Treasurer

SIR DOUGLAS VEALE, C.B.E., D.C.L.

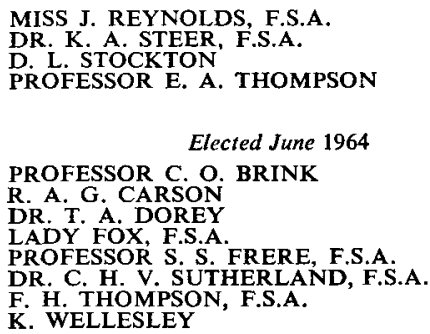

\section{Auditors}

MESSRS. DAVEY, BRIDGWATER AND CO.

\section{Editorial Committee}

DR. A. H. MCDONALD PROFESSOR A. D. MOMIGLIANO SIR IAN RICHMOND PROFESSOR F. W. WALBANK PROFESSOR G. W. WILLIAMS with the co-operation of SIR FRANK ADCOCK and SIR RONALD SYME

Editor: F. A. LEPPER, Corpus Christi College, Oxford Assistant Editor: D. R. WILSON, Haverfield Library, Ashmolean Museum, Oxford Review Editor : PROFESSOR F. W. WALBANK, Hope Lodge, 5 Poplar Road, Oxton, Birkenhead

\section{Library Committee}

M. W. FREDERIKSEN
PROFESSOR S. S. FRERE, F.S.A.

Hon. Librarian

PROFESSOR O. SKUTSCH

Hon. Secretary

MRS. J. S. BENNETT, M.A.
Secretary MRS. P. GILBERT, B.A
R. M. OGILVIE
PROFESSOR H.

H. SCULLARD

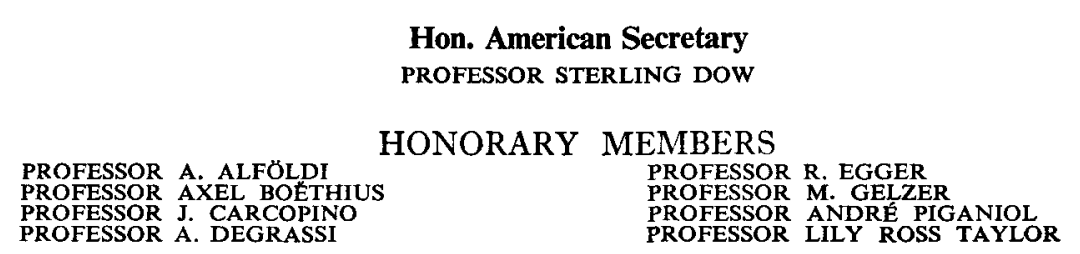

